\title{
Cellular crosstalk mechanism of Toll-like receptors in gingival overgrowth (Review)
}

\author{
TAMILSELVAN SUBRAMANI ${ }^{1}$, VIDHYA RATHNAVELU $^{2}$, \\ NOORJAHAN BANU ALITHEEN ${ }^{1}$ and PARASURAMAN PADMANABHAN ${ }^{3}$
}

\begin{abstract}
${ }^{1}$ Department of Cell and Molecular Biology, Faculty of Biotechnology and Biomolecular Sciences, University Putra Malaysia, Serdang, Selangor 43400, Malaysia; ${ }^{2}$ Department of Oral and Maxillofacial Pathology, Faculty of Dental Science, Sri Ramachandra University, Chennai 600116, India; ${ }^{3}$ The Lee Kong Chian School of Medicine, Nanyang Technological University, Singapore 637553, Republic of Singapore
\end{abstract}

Received June 5, 2014; Accepted January 21, 2015

DOI: $10.3892 / \mathrm{ijmm} .2015 .2144$

\begin{abstract}
Gingival overgrowth is an undesirable outcome of systemic medication and is evidenced by the accretion of collagenous components in gingival connective tissues along with diverse degrees of inflammation. Phenytoin therapy has been found to induce the most fibrotic lesions in gingiva, cyclosporine caused the least fibrotic lesions, and nifedipine induced intermediate fibrosis in drug-induced gingival overgrowth. In drug-induced gingival overgrowth, efficient oral hygiene is compromised and has negative consequences for the systemic health of the patients. Toll-like receptors (TLRs) are involved in the effective recognition of microbial agents and play a vital role in innate immunity and inflammatory signaling responses. TLRs stimulate fibrosis and tissue repairs in several settings, although with evident differences between organs. In particular, TLRs exert a distinct effect on fibrosis in organs with greater exposure to TLR ligands, such as the gingiva. Cumulative evidence from diverse sources suggested that TLRs can affect gingival overgrowth in several ways. Numerous studies have demonstrated the expression of TLRs in gingival tissues and suggested its potential role in gingival inflammation, cell proliferation and synthesis of the extracellular matrix which is crucial to the development of gingival overgrowth. In the present review, we assessed the role of TLRs on individual cell populations in gingival tissues that contribute to the progression of gingival inflammation, and the involvement of TLRs in the development of gingival
\end{abstract}

Correspondence to: Dr Noorjahan Banu Alitheen, Department of Cell and Molecular Biology, Faculty of Biotechnology and Biomolecular Sciences, University Putra Malaysia, Serdang, Selangor 43400, Malaysia

E-mail: noorjahan@upm.edu.my

Key words: Toll-like receptor, pathogen-associated molecular pattern, inflammation, gingival overgrowth, transforming growth factor, endothelin-1, angiotensin II overgrowth. These observations suggest that TLRs provide new insight into the connection among infection, inflammation, drugs and gingival fibrosis, and are therefore efficient therapeutic target molecules. We hypothesize that TLRs are critical for the development and progression of gingival overgrowth, and thus blocking TLR expression may serve as a novel target for antifibrotic therapy.

\section{Contents}

1. Introduction

2. TLR expression and signaling in gingival tissues

3. TLRs and drug-induced gingival overgrowth

4. Current development in TLR-targeted therapeutics

5. Conclusion and future directions

\section{Introduction}

Drug-induced gingival overgrowth is an adverse reaction mostly associated with three types of regularly recommended drugs, i.e., immunosuppressants (cyclosporine) (1), antiepileptic drugs (phenytoin) (2) and calcium channel blockers (verapamil, diltiazem and nifedipine) (3-6). As gingival enlargement develops, regular oral hygiene practice is disturbed and progressively severe pain develops, often leading to disfiguration. Several etiological factors triggering gingival overgrowth have been studied and it was shown that the degrees of inflammation, fibrosis, dose, duration, quality of oral hygiene and identity of the drug, local bacterial plaque accumulation, individual susceptibility and environmental influences contribute to the progression of gingival overgrowth $(7,8)$. Bacterial biofilm, one of the primary etiologic factors, harbors several hundred diverse bacterial species that colonize the sulcus and periodontal pockets, and initiate inflammation in the gingival tissues, leading to gingivitis and periodontitis. These bacteria have a number of structural components that directly destroy the periodontal tissues, or stimulate host cells to initiate a wide range of inflammatory responses. These inflammatory 
responses are envisioned to overcome the microbial challenge, however, they are frequently responsible for further tissue destruction. The changes in the morphology of gingiva during gingival overgrowth lead to the retention of dental plaque which stimulates the inflammation (8). At the molecular level, an excess of mediators are released following gingival inflammation that contribute to the regulation of fibrogenic and regenerative signals (8). Out of several fibrogenic promoters, platelet-derived growth factor (PDGF) and transforming growth factor- $\beta$ (TGF- $\beta$ ) play a vital role in the progression of fibrosis. It has been reported that PDGF and TGF- $\beta$ were overexpressed in the promotion of spontaneous fibrosis of the kidney, liver, lung and gingiva (9-12). In addition to PDGF and TGF- $\beta$, a number of other mediators such as angiotensin II, endothelin-1, chemokines, leptin, interleukin-4 (IL-4), IL-6 and IL-13 play vital roles in fibrogenesis (13). Despite their protuberant role in fibrogenesis, recent studies indicate Toll-like receptors (TLRs), a group of receptors that regulate innate and adaptive immune responses, as significant modulators of inflammation during fibrosis (14-16). TLRs recognize pathogen-associated molecular patterns (PAMPs) and activate innate and adaptive immune responses to confiscate pathogens. In this review, we analyzed the role of TLRs in gingival overgrowth and discussed the possibility that TLRs may reveal innovative targets for the prevention or treatment of gingival overgrowth.

\section{TLR expression and signaling in gingival tissues}

Microbial biofilm induces the inflammatory process of gingival tissues and supporting structures, leading to gingivitis and periodontitis. Oral pathogens present in the biofilm initiate periodontal diseases by stimulating the host immune response. Epithelial cells and connective tissues of gingiva express TLRs, which are crucial in the inflammatory response (17). TLRs stimulate signaling via two main pathways. The first one is myeloid differentiation factor 88 (MyD88)-dependent, while and the second one is MyD88-independent. Following initiation, pro-inflammatory cytokines and type I interferons (IFNs) are produced. The production of pro-inflammatory cytokines is dependent on adaptor molecules MyD88 and TIR-associated protein (TIRAP), whereas IFNs are produced by TIR domain-containing adaptor protein-inducing IFN- $\beta$ (TRIF) and TRIF-related adaptor molecules (TRAM) (18-21). Generally, bacterial triacylated lipopeptides are recognized by heterodimers of the TLR1/TLR2 complex (22). Bacterial lipoproteins and peptidoglycans derived from Gram-positive bacteria, are recognized by TLR-2. Endogenous ligands such as heat shock proteins are also recognized by TLR-2 (23). Double-strand DNA and its synthetic analogue polyinosine-deoxycytidylic acid are recognized by TLR-3, a potent stimulator of type I IFNs (24). The extensively studied TLR-4 recognizes a wide range of ligands mainly associated with Gram-negative bacteria. Apart from microbial pathogens, TLR-4 also recognizes a series of endogenous ligands in the circulation that are released during necrosis and cell stress. Following stimulation, TLR-4 activates a complex downstream signaling pathway leading to the stimulation of transcription factors, principally nuclear factor- $\kappa \mathrm{B}(\mathrm{NF}-\kappa \mathrm{B})$ induces the stimulation of inflammatory genes, such as tumor necrosis factor- $\alpha$ (TNF- $\alpha)$, IL-1, IL-6 and IL-8 $(25,26)$. The constant domain D1 present in the monomeric flagellin of bacteria is recognized by TLR-5. The bacterial triacylated lipopeptides are recognized by the TLR1/TLR6 complex (22) and the bacterial DNA is recognized by TLR-9 through unmethylated $\mathrm{CpG}$ motifs (27). A summary of TLR ligands, cellular, gene location and the effector molecules induced are listed in Table I.

In gingiva, bacteria that inhabit the sulcus and pockets are attached to the gingival epithelial cells by using their fimbriae. These epithelial cells protect the organism from potentially lethal oral pathogens and offer a surface that tolerates microorganisms and favors the exchange of nutrients. The gingival epithelial cells express almost all TLRs, such as TLR1-9 (27). The oral epithelial cells that harbor TLRs have the potential to stimulate pro-inflammatory cytokines IL-1 $\beta$, IL-6, IL-8 and TNF- $\alpha$ following ligation with their respective ligands (28). Furthermore, IL-8, a well-known chemoattractant enhances the migration of neutrophils from the circulation (29). Simultaneously, epithelial cells produced matrix metalloproteinases (MMPs) in response to PAMP, causing direct damage to periodontal tissues (30). These MMPs are structurally associated with endopeptidases and capable of degrading virtually all extracellular matrix (ECM) and basement membrane components.

Gingival connective tissues predominantly constituted by gingival fibroblasts that produce ECM are involved in tissue regeneration by replacing the injured or disrupted tissue. The expression of TLRs on gingival fibroblasts has generated substantial interest towards this cell population in inflammation in addition to their well-documented fibrogenic effects. It has been demonstrated that the innate immune responses of gingival fibroblasts produced various inflammatory cytokines, such as IL-1, IL-6 and IL-8, following stimulation with lipopolysaccharides from periodontopathic bacteria $(31,32)$. Gingival fibroblast stimulation with lipopolysaccharides induces the production of chemokines such as RANTES, IP-10, MCP-1, MIP-1 $\alpha$ and MIP-1 $\beta$ (33). Additionally, the stimulated gingival fibroblasts produce large amounts of collagen and ECM proteins (Fig. 1). Endothelial cells also strongly participate in pathogen recognition, which, due to their blood-exposed location, assigns these cells a key role in the initial responses to pathogens that have reached the blood. Accumulating evidence suggests a significant role for gingival endothelial cell involvement in innate immunity and in controlling the host responses to pathogens. As indicated in previous investigations, endothelial cells express functional TLR-2, TLR-4 and TLR-9 (34,35), while the hypothesized contribution of endothelial cell activities induced via TLRs in pathological processes such as gingivitis and chronic periodontitis has been suggested.

\section{TLRs and drug-induced gingival overgrowth}

The pathogenesis of drug-induced gingival overgrowth seems complex, especially the involvement of quality of plaque control. Animal and human models have shown that plaque-mediated inflammatory changes have a substantial role in the pathogenesis of drug-induced gingival overgrowth (36-39). The drug may be an important factor in the pathogenesis of gingival fibrosis by reducing cell signaling, 
Table I. Summary of predominant cell location, encoding gene location, ligands, and the effector molecules induced by TLRs.

\begin{tabular}{|c|c|c|c|c|}
\hline $\begin{array}{l}\text { Toll-like } \\
\text { receptor }\end{array}$ & $\begin{array}{l}\text { Predominant } \\
\text { cellular location } \\
\text { (membrane) }\end{array}$ & $\begin{array}{l}\text { Encoding } \\
\text { gene location } \\
\text { (chromosomes) }\end{array}$ & Ligands & $\begin{array}{c}\text { Effector molecules } \\
\text { induced } \\
\text { (Inflammatory cytokines) }\end{array}$ \\
\hline TLR-1 & Plasma & 4 & Triacyl lipopeptides, modulin & TNF- $\alpha$ and IL- 6 \\
\hline TLR-2 & Plasma & 4 & $\begin{array}{l}\text { Glycolipids, triacyl lipopeptides, heat shock } \\
\text { proteins, high mobility group box } 1 \text { protein, } \\
\text { rare LPS species (Porphyromonas gingivalis), } \\
\text { lipopeptides, lipoteichoic acid, measles } \\
\text { haemagglutinin, mannuronic acids, neisseria } \\
\text { porins, peptidoglycan, zymosan ( } \beta \text {-glucan), } \\
\text { bacterial fimbriae, Yersinia virulence factors, } \\
\text { CMV virions, saturated fatty acids }\end{array}$ & $\begin{array}{l}\text { TNF- } \alpha, \text { IL- } 4,-5 \text {, } \\
-6 \text { and }-21\end{array}$ \\
\hline TLR-3 & Endosomal & 4 & dsRNA (self and viral) & $\begin{array}{l}\text { TNF- } \alpha, \text { IL- } 4 \text { and }-6 \\
\text { type I INFs }\end{array}$ \\
\hline TLR-4 & Plasma & 9 & $\begin{array}{l}\text { Lipopolysaccharides, saturated free fatty acids, } \\
\text { fibrinogen, fibronectin, heat shock proteins, } \\
\text { flavolipins, Streptococcus pneumoniae pneumolysin, } \\
\text { heparan sulfate, hyaluronic acid, high mobility group } \\
\text { box } 1 \text { protein, MMTV envelope proteins, nickel, } \\
\text { paclitaxel, RSV fusion protein, respiratory syncytial } \\
\text { virus coat protein, mannuronic acid polymers, } \\
\text { teichuronic acids, bacterial fimbriae, surfactant } \\
\text { protein A, } \beta \text {-defensin } 2\end{array}$ & $\begin{array}{l}\text { TNF- } \alpha, \text { IL-4, }-5, \\
-6 \text { and }-13) ; \\
\text { type I INFs }\end{array}$ \\
\hline TLR-5 & Plasma & 1 & Flagellin & TNF- $\alpha$ and IL-6 \\
\hline TLR-6 & Plasma & 4 & $\begin{array}{l}\text { Diacyl lipopeptides, bacterial cell } \\
\text { wall components, modulin }\end{array}$ & TNF- $\alpha$ and IL- 6 \\
\hline TLR-7 & Endosomal & $\mathrm{X}$ & $\begin{array}{l}\text { Self ssRNA, ssRNA, bropirimine, } \\
\text { loxoribine, imidazoquinoline }\end{array}$ & $\begin{array}{l}\text { TNF- } \alpha \text { and IL- } 6 \\
\text { type I INFs }\end{array}$ \\
\hline TLR-8 & Endosomal & $\mathrm{X}$ & $\begin{array}{l}\text { Self ssRNA, small synthetic compounds, } \\
\text { imidazoquinoline }\end{array}$ & $\begin{array}{l}\text { TNF- } \alpha \text { and IL-6 } \\
\text { type I INFs }\end{array}$ \\
\hline TLR-9 & Endosomal & 3 & Self DNA, unmethylated CpG DNA & $\begin{array}{l}\text { TNF- } \alpha \text { and IL-6; } \\
\text { type I INFs }\end{array}$ \\
\hline
\end{tabular}

TLRs, Toll-like receptors; TNF- $\alpha$, tumor necrosis factor- $\alpha$; IL-6, interleukin-6.

altering the inflammatory response in gingival tissues and favoring bacterial invasion and proliferation. Elimination of the microbial biofilm resulted in reduction of the inflammatory infiltrate and alteration in connective tissue composition of the gingival tissues of patients with drug-induced gingival overgrowth (40). PAMPs are recognized by pattern recognition receptors (PRRs) presented on several cells, including fibroblasts (41). The interaction between PAMPs and PRRs provides a first line of defense during infection and activates numerous proinflammatory chemokines as well as cytokine responses that modulate fibroblast proliferation and ECM synthesis.

Inflammatory and immune mechanisms triggered by non-infectious as well as, possibly even infectious agents, may be important in the development of fibrosis (42). TLR ligands induce $N F-\kappa B$ activation, resulting in the transcription of various types of genes involved in the inflammatory and proliferative responses of cells crucial to gingival overgrowth and ultimately leading to the synthesis and release of inflammatory cytokines which provide a critical link to adaptive immunity $(34,43)$. These inflammatory mediators can exert various fibrogenic effects involving the expression of adhesion molecules on endothelial cells, proliferation of fibroblasts, activation of immune cells, and stimulation of the acute-phase response. In addition, TLR ligands can directly activate fibroblasts and promote fibrogenesis (44-46). TLR-2 and TLR-4 stimulate a series of events including $\mathrm{NF}-\kappa \mathrm{B}$ activation following the recognition of the cell-wall component lipoproteins and peptidoglycan, and recognition of the outer membrane component lipopolysaccharides, respectively. NF- $\kappa \mathrm{B}$ activation leads to cytokine production and expression of adhesion molecules in gingival fibroblasts (27). Therefore, considering the role of 

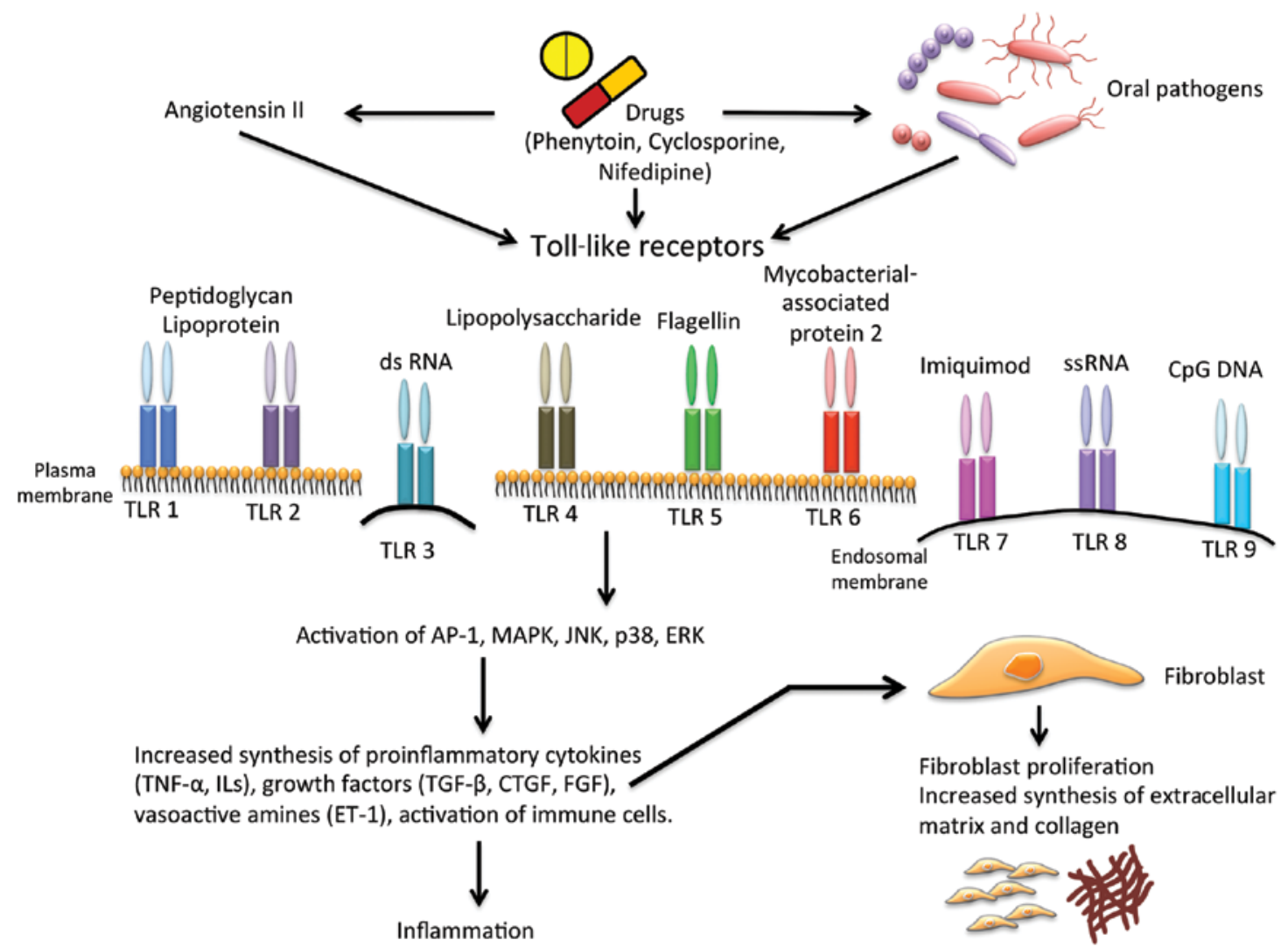

Figure 1. Schematic representation of Toll-like receptor (TLR) signaling in drug-induced gingival overgrowth. TLRs stimulated by endogenous and exogenous ligands and TLRs activate adaptor molecules, which trigger conserved signaling pathways culminating in a profibrotic response consisting of the induction of inflammatory and fibrotic genes that leads to proliferation of gingival fibroblast, accumulation of extracellular matrix (ECM) and collagen in gingival tissues.

TLRs in the recognition of bacterial components and initiation of host response via the release of several inflammatory mediators, TLRs have a strong role in the pathogenesis of gingival fibrosis. An in vitro study using hamster cells treated with phenytoin and cyclosporine showed that cyclosporine increased signaling by TLR 2 and TLR4, while phenytoin decreased this signaling with a decreased expression of adhesion molecules such as CD54 (47).

The reduction in cell signaling induced by drugs such as phenytoin may alter the inflammatory response in gingival tissues, favoring bacterial invasion and proliferation and, therefore, may be an important factor in the pathogenesis of gingival fibrosis (48). Furthermore, cyclosporine-induced gingival overgrowth patients had a significantly higher number of TLR-4 expressing cells in the basal cell layer of the epithelium, as well as in connective tissue compared to healthy subjects (42). Lim et al (49) demonstrated an association between cyclosporine-induced renal injury and activation of innate immunity through TLR- 2 and TLR- 4 expression in renal tissues of rats and reported an increased TLR-2 and TLR-4 mRNA and protein expression in rat kidney. Another study by Suzuki et al (50) showed that TLR-mediated inflammatory responses were positively regulated by cyclosporine in human gingival fibroblasts. Moreover, it has been reported that deficiency of MyD88, the common adaptor for all TLRs except TLR-3, protects mice from inflammation and fibrosis (51). In contrast to TLR-2 and TLR-4, TLR-9 appears to promote lung fibrosis (52). Those results were confirmed by another study, in which TLR-4 deficient mice exhibited a significant reduction in fibroblast accumulation and renal fibrosis (53). Together together, those studies suggest that TLRs, via their common adaptor MyD88, negatively affect tissue remodeling and fibrotic development.

TLRs activate immune cells including mast cells. The activated mast cells degranulate and release various mediators such as ILs, TNF- $\alpha$ and protease enzymes such as chymase and tryptase (54). Findings of our earlier studies suggest that an increased expression of mast cells and its mediators was observed in drug-induced gingival overgrowth compared to healthy gingival tissues (55). Mast-cell chymase actively participate in the production of locally expressed angiotensin II (Ang II) and endothelin-1 in gingiva. Ang II is the effector peptide of the renin angiotensin system, which acts as a major role in mediating contractile activity of vascular smooth muscle, aldosterone release in the adrenal gland, regulation of collagen synthesis and growth-modulating effects on fibroblasts $(54,56,57)$. Furthermore, Ang II activates TLR4 through AT1 receptor and subsequent extracellular signal-regulated kinase (ERK) $1 / 2$ and mediates $N F-\kappa B$ to initiate the expression of cytokines involved in the inflammatory and profibrotic response. Our previous study showed elevated TLR4 expression in gingival tissues (17) and the significant increase of Ang II in cyclosporine-induced gingival overgrowth (58). Consequently, TLR4 is closely involved in the Ang II-induced inflammatory response and drug-induced gingival overgrowth. On the other hand, endothelin-1, a potent vasoconstrictor secreted from endothelial cells $(59,60)$, can induce ECM production $(61,62)$. The source of ET-1 is not 
restricted to endothelial cells. Human macrophages have been shown to produce ET-1 in response to lipopolysaccharide (63), and human monocyte-derived dendritic cells secrete ET-1 in response to TLR2 and TLR4 agonists (64). Previously we showed a significant increase of ET-1 in cyclosporine-treated human gingival fibroblast cells (65). ET-1 stimulates the synthesis of collagen by gingival fibroblasts from different species, including humans (66-70). Further profibrotic effects of ET-1 occur at the level of MMPs, with evidence that ET-1, acting via the ETA receptor, can reduce collagenase activity (71). These findings showed the potential role of the TLRs-dependent signaling pathway in modulating fibrotic events in drug-induced gingival overgrowth.

TLR activation also upregulates many growth factors such as TGF- $\beta$, VEGF, CXCR4, and adhesion molecules such as ICAM-1 (70-73). TGF- $\beta$ has been the most intensively studied regulator of the ECM and has been associated with the development of fibrosis in a number of diseases (74-77). Once activated, TGF- $\beta$ signals trigger signaling intermediates known as Smad proteins via transmembrane receptors and modulate the transcription of vital target genes including procollagen I and III (78). Gingival fibrosis is reduced in Smad-deficient mice, confirming the significant role for the TGF- $\beta$ signaling pathway (79). Furthermore, it has been reported that loss of TGF- $\beta$ signaling in fibroblasts triggers intraepithelial neoplasia, suggesting that TGF- $\beta 1$ signaling critically regulates the activity of fibroblasts as well as the oncogenic potential of neighboring epithelial cells (80). In pulmonary fibrosis, alveolar macrophages are thought to produce almost all of the active TGF- $\beta$ (81). Nevertheless, Smad3/TGF- $\beta 1$-independent mechanisms of fibrosis have been demonstrated in lung and other tissues (82-84), suggesting that profibrotic mediators such as IL-4, IL-5, IL-13 and IL-21 can act independently from the TGF $\beta /$ Smad-signaling pathway to stimulate collagen deposition. The connection between TGF- $\beta$ and ET-1 has been established, and several lines of evidence indicate that transdifferentiation of fibroblasts occurs in response to the concerted actions of TGF- $\beta$, ET- 1 and Ang II (85). Activation of AP-1 and the MAPKs c-jun N-terminal kinase (JNK), p38 and ERK1/2 are other classical signals regulated by TLR signaling $(86,87)$. AP-1 transcriptional complexes play a pivotal role in drug-induced gingival overgrowth. AP-1 can be activated through the TLR Myd88-dependent pathway by a variety of growth factors and cytokines (88). AP-1 induced the activation of FOS and Jun, which are observed in many fibrotic conditions (89). Our group previously demonstrated the elevated expression of Jun and Fos in cyclosporine-induced gingival overgrowth (90). The expression of Jun and Fos activates proliferation and ECM synthesis in gingival fibroblasts. Taken together, there is a significant amount of evidence for the involvement of TLRs in drug-induced gingival overgrowth.

\section{Current development in TLR-targeted therapeutics}

Evidence of the involvement of TLRs in gingival fibrosis largely comes from overexpression in fibrosis and their activation triggering enhancement in the pathogenesis of diseases. Inflammatory mediators such as TNF- $\alpha$ and ILs, which are produced as a consequence of the activation of TLRs have been successfully targeted in an effort to treat inflammatory diseases. Additionally, targeting central upstream mediators in the inflammatory cascades such as the TLRs may modulate pathway activation at an earlier point and are therefore also likely to be effective in the manipulation of the immune system to reduce disease severity. A substantial amount of research has been conducted aiming to develop TLR-targeted drugs for human use; however, only a few have been approved thus far. The ubiquitin-modifying enzyme and zinc-finger protein, A20, has been reported to regulate TLR-4 signaling $(91,92)$. A20 can suppress both TLR-2- and TLR-4-induced IL-8 expression in airway epithelial cells (93). OPN305 is a humanized anti-TLR-2 monoclonal antibody that has potential to block TLR-1/2- and TLR-2/6-mediated signaling and decrease TLR-2-mediated pro-inflammatory cytokine production (94). NI0101 is a TLR-4 epitope-specific antibody targeted towards TLR-4 and inhibits TLR-4 dimerization and decreases pro-inflammatory cytokine production. This antibody remains in the preclinical developmental stage and has some potential indications including rheumatoid arthritis, asthma, acute lung injury and acute respiratory distress syndrome (95). AV411 is another TLR-4-targeted antagonist that has potential utility for the treatment of neurological indications (96). In addition to antibodies, a synthetic analog of lipid A eritoran is targeted TLR-4, which inhibited the production of LPS-induced TNF- $\alpha$ and IL-6 (97,98). IMO3100 is a dual TLR-7/TLR-9 antagonist that inhibits TLR ligand-induced gene expression. Additionally, IMO8400 is a drug capable of antagonising TLR-7, TLR-8 and TLR-9, that has shown efficacy in mouse models of lupus (99). Conserning existing conventional therapies, evidence suggests that many of these approaches directly or indirectly affect TLR-mediated responses (100). Although no specific published data are available on drug-induced gingival overgrowth, there is a substantial evidence suggesting that TLRs are a good target for drug-induced gingival overgrowth. By understanding in more detail the manner in which these modulate the activity of TLRs to good effect, we can design TLR-directed interventions that selectively inhibit the inflammatory component of the cascade while retaining the anti-microbial component.

\section{Conclusion and future directions}

Evidence of the contribution of TLRs in fibrosis greatly extends this understanding beyond innate immunity, and provides important insights into body responses to diseases. As a major portal of entry for microbes, the gingiva is a key component of the innate immune system. Oral pathogens encounter a number of effective defense mechanisms designed to rapidly counteract potential damage, inhibit colonization and protect against invasion by pathogens. The existence of TLRs equips gingival tissues with a uniquely designed mechanism for controlling microbial infection. However, drug-induced gingival overgrowth is a disease in which the gingival epithelial cells, endothelial cells and fibroblasts stimulate inflammatory mediators and profibrotic mediators through TLRs and facilitate the accumulation of collagen and ECM in gingiva. Conflicting roles of TLRs in various organs and different forms of tissue response make it virtually impossible to outline distinct greater functions for individual TLRs in drug-induced gingival overgrowth. A possible explanation may be the differential 
contribution of endogenous and exogenous ligands to TLR activation, which likely depends on the anatomical localization and the related exposure to microbes. Furthermore, drugs such as cyclosporine stimulate TLR expression in gingival tissues. Thus modulation of TLRs was important in drug-induced gingival overgrowth. Suppression of TLRs responses by the use of appropriate inhibitors may reduce the chronic inflammatory characteristic of this disease. Thus, new therapeutics designed to selectively activate or inhibit TLR function specifically and reversibly are powerful tools for the prevention and treatment of the drug-induced gingival overgrowth.

\section{References}

1. McGaw T, Lam S and Coates J: Cyclosporin-induced gingival overgrowth: correlation with dental plaque scores, gingivitis scores, and cyclosporin levels in serum and saliva. Oral Surg Oral Med Oral Pathol Oral Radiol Endod 64: 293-297, 1987.

2. Perlík F, Kolínová M, Zvárová J and Patzelová V: Phenytoin as a risk factor in gingival hyperplasia. Ther Drug Monit 17: 445-448, 1995.

3. Seymour RA: Calcium channel blockers and gingival overgrowth. Br Dent J 170: 376-379, 1991.

4. Miller CS and Damm DD: Incidence of verapamil-induced gingival hyperplasia in a dental population. J Periodontol 63: 453-456, 1992.

5. Nishikawa S, Nagata T, Morisaki I, Oka T and Ishida H: Pathogenesis of drug-induced gingival overgrowth. A review of studies in the rat model. J Periodontol 67: 463-471, 1996.

6. Ellis JS, Seymour RA, Steele JG, Robertson P, Butler TJ and Thomason JM: Prevalence of gingival overgrowth induced by calcium channel blockers: a community-based study. J Periodontol 70: 63-67, 1999.

7. Marshall RI and Bartold PM: A clinical review of drug-induced gingival overgrowths. Aust Dent J 44: 219-232, 1999.

8. Seymour RA, Ellis JS and Thomason JM: Risk factors for drug-induced gingival overgrowth. J Clin Periodontol 27: 217-223, 2000 .

9. Yoshida M, Sakuma J, Hayashi S, Abe K, Saito I, Harada S, Sakatani M, Yamamoto S, Matsumoto N, Kaneda Y, et al: A histologically distinctive interstitial pneumonia induced by overexpression of the interleukin 6 , transforming growth factor beta 1, or platelet-derived growth factor B gene. Proc Natl Acad Sci USA 92: 9570-9574, 1995

10. Campbell JS, Hughes SD, Gilbertson DG, Palmer TE, Holdren MS Haran AC, Odell MM, Bauer RL, Ren HP, Haugen HS, Yeh MM and Fausto N: Platelet-derived growth factor $\mathrm{C}$ induces liver fibrosis, steatosis, and hepatocellular carcinoma. Proc Natl Acad Sci USA 102: 3389-3394, 2005.

11. Czochra P, Klopcic B, Meyer E, Herkel J, Garcia-Lazaro JF, Thieringer F, Schirmacher P, Biesterfeld S, Galle PR, Lohse AW and Kanzler S: Liver fibrosis induced by hepatic overexpression of PDGF-B in transgenic mice. J Hepatol 45: 419-428, 2006.

12. Yoshida T, Nagata $\mathbf{J}$ and Yamane A: Growth factors and proliferation of cultured rat gingival cells in response to cyclosporin $\mathrm{A}$ J Periodontal Res 40: 11-19, 2005.

13. Wynn TA: Cellular and molecular mechanisms of fibrosis. J Pathol 214: 199-210, 2008.

14. Bataller R and Brenner DA: Liver fibrosis. J Clin Invest 115 : 209-218, 2005

15. Wynn TA: Integrating mechanisms of pulmonary fibrosis. J Exp Med 208: 1339-1350, 2011.

16. Huebener P and Schwabe RF: Regulation of wound healing and organ fibrosis by toll-like receptors. Biochim Biophys Acta 1832: $1005-1017,2013$

17. Sarah SM, Tamilselvan S, Kamatchiammal S and Suresh R Expression of Toll-like receptors 2 and 4 in gingivitis and chronic periodontitis. Ind J Dent Res 17: 114-116, 2006.

18. O'Neill LA, Fitzgerald KA and Bowie AG: The Toll-IL-1 receptor adaptor family grows to five members. Trends Immunol 24 286-290, 2003

19. Yamamoto M, Sato S, Hemmi H, Hoshino K, Kaisho T, Sanjo H, Takeuchi O, Sugiyama M, Okabe M, Takeda K and Akira S: Role of adaptor TRIF in the MyD88-independent toll-like receptor signaling pathway. Science 301: 640-643, 2003.
20. Yamamoto M, Sato S, Hemmi H, Sanjo H, Uematsu S, Kaisho T, Hoshino K, Takeuchi O, Kobayashi M, Fujita T, Takeda K and Akira S: Essential role for TIRAP in activation of the signaling cascade shared by TLR2 and TLR4. Nature 420: 324-329, 2002.

21. Yamamoto M, Sato S, Hemmi H, Uematsu S, Hoshino K, Kaisho T, Takeuchi O, Takeda K and Akira S: TRAM is specifically involved in the Toll-like receptor 4-mediated MyD88-independent signaling pathway. Nat Immunol 4: 1144-1150, 2003.

22. Akira S, Uematsu S and Takeuchi O: Pathogen recognition and innate immunity. Cell 124: 783-801, 2006.

23. Ohashi K, Burkart V, Flohé S and Kolb H: Cutting edge: heat shock protein 60 is a putative endogenous ligand of the toll-like receptor-4 complex. J Immunol 164: 558-561, 2000.

24. Oshiumi H, Matsumoto M, Funami K, Akazawa T and Seya T: TICAM-1, an adaptor molecule that participates in Toll-like receptor 3-mediated interferon-beta induction. Nat Immunol 4: 161-167, 2003.

25. Fitzgerald KA, Palsson-McDermott EM, Bowie AG, Jefferies CA, Mansell AS, Brady G, Brint E, Dunne A, Gray P, Harte MT, McMurray D, Smith DE, Sims JE, Bird TA and O'Neill LA: Mal (MyD88-adapter-like) is required for Toll-like receptor-4 signal transduction. Nature 413: 78-83, 2001.

26. Medzhitov R: Recognition of microorganisms and activation of the immune response. Nature 449: 819-826, 2007.

27. Uehara A and Takada H: Functional TLRs and NODs in human gingival fibroblasts. J Dent Res 86: 249-254, 2007.

28. Yan P, Yue J and Jiang H: Expression of ICAM-1/LFA-1 in the pocket area of adult periodontitis. Zhonghua Kou Qiang Yi Xue Za Zhi 34: 106-108, 1999 (In Chinese).

29. Han YW, Shi W, Huang GT, Kinder Haake S, Park NH, Kuramitsu $\mathrm{H}$ and Genco RJ: Interactions between periodontal bacteria and human oral epithelial cells: Fusobacterium nucleatum adheres to and invades epithelial cells. Infect Immun 68: 3140-3146, 2000.

30. Warner RL, Bhagavathula N, Nerusu KC, Lateef H, Younkin E, Johnson KJ and Varani J: Matrix metalloproteinases in acute inflammation: induction of MMP-3 and MMP-9 in fibroblasts and epithelial cells following exposure to pro-inflammatory mediators in vitro. Exp Mol Pathol 76: 189-195, 2004.

31. Takada H, Mihara J, Morisaki I and Hamada S: Induction of interleukin-1 and -6 in human gingival fibroblast cultures stimulated with Bacteroides lipopolysaccharides. Infect Immun 59: 295-301, 1991.

32. Tamura M, Tokuda M, Nagaoka S and Takada H: Lipopolysaccharides of Bacteroides intermedius (Prevotella intermedia) and Bacteroides (Porphyromonas) gingivalis induce interleukin-8 gene expression in human gingival fibroblast cultures. Infect Immun 60: 4932-4937, 1992.

33. Seki E, De Minicis S, Osterreicher CH, Kluwe J, Osawa Y, Brenner DA and Schwabe RF: TLR4 enhances TGF-beta signaling and hepatic fibrosis. Nat Med 13: 1324-1332, 2007.

34. Faure E, Equils O, Sieling PA, Thomas L, Zhang FX, Kirschning CJ, Polentarutti N, Muzio M and Arditi M: Bacterial lipopolysaccharide activates NF-kappaB through toll-like receptor 4 (TLR-4) in cultured human dermal endothelial cells. Differential expression of TLR-4 and TLR-2 in endothelial cells. J Biol Chem 275: 11058-11063, 2000.

35. Li J, Ma Z, Tang ZL, Stevens T, Pitt B and Li S: CpG DNAmediated immune response in pulmonary endothelial cells. Am J Physiol Lung Cell Mol Physiol 287: L552-L558, 2004

36. Kataoka M, Kido J, Shinohara Y and Nagata T: Drug-induced gingival overgrowth - a review. Biol Pharm Bull 28: 1817-1821, 2005.

37. Romanos GE, Strub JR and Bernimoulin JP: Immunohistochemical distribution of extracellular matrix proteins as a diagnostic parameter in healthy and diseased gingiva. J Periodontol 64: 110-119, 1993.

38. Seymour RA, Smith DG and Rogers SR: The comparative effect of azathioprine and cyclosporine on some gingival health parameters of renal transplant patients. A longitudinal study. J Clin Periodontol 14: 610-613, 1987.

39. Seymour RA and Jacobs DJ: Cyclosporine and the gingival tissues. J Clin Periodontol 19: 1-11, 1992.

40. Aimetti M, Romano F, Marsico A and Navone R: Non-surgical periodontal treatment of cyclosporine A-induced gingival overgrowth: immunohistochemical results. Oral Dis 14: 244-250, 2008.

41. Nurmenniemi PK, Pernu HE, Laukkanen P and Knuuttila ML: Macrophage subpopulations in gingival overgrowth induced by nifedipine and immunosuppressive medication. J Periodontol 73: 1323-1330, 2002. 
42. Becerik S, Ozsan N, Gürkan A, Oztürk VÖ, Atilla G and Eminqil G: Toll like receptor 4 and membrane-bound CD14 expressions in gingivitis, periodontitis and $\mathrm{CsA}$-induced gingival overgrowth. Arch Oral Biol 56: 456-465, 2011.

43. Stoll LL, Denning GM,Li WG, Rice JB, Harrelson AL, Romig SA, Gunnlaugsson ST, Miller FJ Jr and Weintraub NL: Regulation of endotoxin-induced proinflammatory activation in human coronary artery cells: expression of functional membrane-bound CD14 by human coronary artery smooth muscle cells. J Immunol 173: 1336-1343, 2004.

44. Meneghin MD and Hogaboam C: Infectious disease, the innate immune response, and fibrosis. J Clin Invest 117: 530-538, 2007.

45. Otte JM, Rosenberg IM and Podolsky DK: Intestinal myofibroblasts in innate immune responses of the intestine. Gastroenterol 124: 1866-1878, 2003.

46. Coelho AL, Hogaboam CM and Kunkel SL: Chemokines provide the sustained inflammatory bridge between innate and acquired immunity. Cytokine Growth Factor Rev 16: 553-560, 2005.

47. Kawai T and Akira S: TLR signaling. Cell Death Differ 13: 816-825, 2006

48. Subramani T, Rathnavelu V, Yeap SK and Alitheen NB: Influence of mast cells in drug-induced gingival overgrowth. Mediators Inflamm 2013: 275172, 2013.

49. Lim SW, Li C, Ahn KO, Kim J, Moon IS, Ahn C, Lee JR and Yang CW: Cyclosporine-induced renal injury induces toll-like receptor and maturation of dendritic cells. Transplantation 80 : 691-699, 2005

50. Suzuki AM, Yoshimura A, Ozaki Y, Kaneko T and Hara Y: Cyclosporin A and phenytoin modulate inflammatory responses. J Dent Res 88: 1131-1136, 2009.

51. Gasse P, Mary C, Guenon I, Noulin N, Charron S, Schnyder-Candrian S, Schnyder B, Akira S, Quesniaux VF Lagente V, Ryffel B and Couillin I: IL-1R1/MyD88 signaling and the inflammasome are essential in pulmonary inflammation and fibrosis in mice. J Clin Invest 117: 3786-3799, 2007.

52. Trujillo G, Meneghin A, Flaherty KR, Sholl LM, Myers JL, Kazerooni EA, Gross BH, Oak SR, Coelho AL, Evanoff H Day E, Toews GB, Joshi AD, Schaller MA, Waters B, Jarai G, Westwick J, Kunkel SL, Martinez FJ and Hogaboam CM: TLR9 differentiates rapidly from slowly progressing forms of idiopathic pulmonary fibrosis. Sci Tranl Med 2: 57ra82, 2010.

53. Campbell MT, Hile KL, Zhang H, Asanuma H, Vanderbrink BA Rink RR and Meldrum KK: Toll-like receptor 4: a novel signaling pathway during renal fibrogenesis. J Surg Res 168: e61-e69, 2011.

54. Mulrow PJ: The intrarenal renin-angiotensin system. Curr Opin Nephrol Hypertens 2: 41-44, 1993.

55. Dzau VJ: Cell biology and genetics of angiotensin in cardiovascular disease. J Hypertens Suppl 12: S3-S10, 1994.

56. Subramani T, Senthilkumar K and Periasamy S: Histochemical expression of mast cell chymase in chronic periodontitis and cyclosporine-induced gingival overgrowth. J Histol 2013: ID812842, 2013.

57. Timmermans PB, Benfield P, Chiu AT, Herblin WF, Wong PC and Smith RD: Angiotensin II receptors and functional correlates. Am J Hypertens 5: S221-S235, 1992.

58. Subramani T, Senthilkumar K, Periasamy S and Rao S: Expression of angiotensin II and its receptors in cyclosporine-induced gingival overgrowth. J Periodontal Res 48: 386-391, 2013.

59. Inoue $A$, Yanagisawa $M$, Kimura $S$, Kasuya $Y$, Miyauchi $T$, Goto $K$ and Masaki T: The human endothelin family: three structurally and pharmacologically distinct isopeptides predicted by three separate genes. Proc Natl Acad Sci USA 86: 2863-2867, 1989.

60. Levin ER: Endothelins. N Engl J Med 333: 356-363, 1995.

61. Leask A: Targeting the TGFbeta, endothelin-1 and CCN2 ax is to combat fibrosis in scleroderma. Cell Signal 20: 1409-1414, 2008

62. Leask A: Potential therapeutic targets for cardiac fibrosis: TGFbeta, angiotensin, endothelin, CCN2, and PDGF, partners in fibroblast activation. Circ Res 106: 1675-1680, 2010.

63. Ehrenreich H, Anderson RW, Fox CH, Rieckmann P, Hoffman GS, Travis WD, Coligan JE, Kehrl JH and Fauci AS: Endothelins, peptides with potent vasoactive properties, are produced by human macrophages. J Exp Med 172: 1741-1748, 1990.

64. Spirig R, Potapova I, Shaw-Boden J, Tsui J, Rieben R and Shaw SG: TLR2 and TLR4 agonists induce production of the vasoactive peptide endothelin-1 by human dendritic cells. Mol Immunol 46: 3178-3182, 2009.

65. Tamilselvan S, Raju SN, Loganathan D, Kamatchiammal S, Abraham G and Suresh R: Endothelin-1 and its receptors ET(A) and ET(B) in drug-induced gingival overgrowth. J Periodontol 78: $290-295,2007$.
66. Kuruvilla L, Nair RR, Umashankar PR, Lal AV and Kartha CC: Endocardial endothelial cells stimulate proliferation and collagen synthesis of cardiac fibroblasts. Cell Biochem Biophyics 47: 65-72, 2007.

67. Nishida M, Onohara N, Sato Y, Suda R, Ogushi M, Tanabe S, Inoue R, Mori Y and Kurose H: Galpha12/13-mediated up-regulation of TRPC6 negatively regulates endothelin-1-induced cardiac myofibroblast formation and collagen synthesis through nuclear factor of activated T cells activation. J Biol Chem 282: 23117-23128, 2007

68. Katwa LC: Cardiac myofibroblasts isolated from the site of myocardial infarction express endothelin de novo. Am J Physiol Heart Circ Physiol 285: H1132-H1139, 2003.

69. Chintalgattu V and Katwa LC: Role of protein kinase Cdelta in endothelin-induced type I collagen expression in cardiac myofibroblasts isolated from the site of myocardial infarction. $\mathrm{J}$ Pharmacol Exp Ther 311: 691-699, 2004.

70. Hafizi S, Wharton J, Chester AH and Yacoub MH: Profibrotic effects of endothelin-1 via the ETA receptor in cultured human cardiac fibroblasts. Cell Physiol Biochem 14: 285-292, 2004.

71. Guarda E, Katwa LC, Myers PR, Tyagi SC and Weber KT: Effects of endothelins on collagen turnover in cardiac fibroblasts. Cardiovas Res 27: 2130-2134, 1993.

72. Kelly MG, Alvero AB, Chen R, Silasi DA, Abrahams VM, Chan S, Visintin I, Rutherford T and Mor G: TLR-4 signaling promotes tumor growth and paclitaxel chemoresistance in ovarian cancer. Cancer Res 66: 3859-3868, 2006.

73. He W, Liu Q, Wang L, Chen W, Li N and Cao X: TLR4 signaling promotes immune escape of human lung cancer cells by inducing immunosuppressive cytokines and apoptosis resistance. Mol Immunol 44: 2850-2859, 2007.

74. Ren T, Wen ZK, Liu ZM, Liang YJ, Guo ZL and Xu L: Functional expression of TLR9 is associated to the metastatic potential of human lung cancer cell: functional active role of TLR9 on tumor metastasis. Cancer Biol Ther 6: 1704-1709, 2007.

75. Zhou M, McFarland-Mancini MM, Funk HM, Husseinzadeh N, Mounajjed T and Drew AF: Toll-like receptor expression in normal ovary and ovarian tumors. Cancer Immunol Immunother 58: 1375-1385, 2009.

76. Sato M, Muragaki Y, Saika S, Roberts AB and Ooshima A: Targeted disruption of TGF-beta1/Smad3 signalling protects against renal tubulointerstitial fibrosis induced by unilateral ureteral obstruction. J Clin Invest 112: 1486-1494, 2003.

77. Border WA, Noble NA, Yamamoto T, Harper JR, Yamaguchi Y, Pierschbacher MD and Ruoslahti E: Natural inhibitor of transforming growth factor-beta protects against scarring in experimental kidney disease. Nature 360: 361-364, 1992.

78. Clouthier DE, Comerford SA and Hammer RE: Hepatic fibrosis, glomerulosclerosis, and a lipodystrophy-like syndrome in PEPCK-TGF-betal transgenic mice. J Clin Invest 100: 2697-2713, 1997.

79. Bonniaud P, Margetts PJ, Ask K, Flanders K, Gauldie J and Kolb M: TGF-beta and Smad3 signaling link inflammation to chronic fibrogenesis. J Immunol 175: 5390-5395, 2005.

80. Sime PJ, Xing Z, Graham FL, Csaky KG and Gauldie J: Adenovector-mediated gene transfer of active transforming growth factor-betal induces prolonged severe fibrosis in rat lung. J Clin Invest 100: 768-776, 1997.

81. Roberts AB, Russo A, Felici A and Flanders KC: Smad3: a key player in pathogenetic mechanisms dependent on TGF-beta. Ann NY Acad Sci 995: 1-10, 2003

82. Bhowmick NA, Chytil A, Plieth D, Gorska AE, Dumont N, Shappell S, Washington MK, Neilson EG and Moses HL: TGF-beta signaling in fibroblasts modulates the oncogenic potential of adjacent epithelia. Science 303: 848-851, 2004.

83. Khalil N, Corne S, Whitman C and Yacyshyn H: Plasmin regulates the activation of cell-associated latent TGF-beta1 secreted by rat alveolar macrophages after in vivo bleomycin injury. Am J Respir Cell Mol Biol 15: 252-259, 1996.

84. Kaviratne M, Hesse M, Leusink M, Cheever AW, Davies SJ, McKerrow JM, Wakefield LM, Letterio JJ and Wynn TA: IL-13 activates a mechanism of tissue fibrosis that is completely TGF-beta independent. J Immunol 173: 4020-4029, 2004.

85. Ma LJ, Yang H, Gaspert A, Carlesso G, Barty MM, Davidson JM, Sheppard D and Fogo AB: Transforming growth factor-beta-dependent and -independent pathways of induction of tubulointerstitial fibrosis in beta6(-/-) mice. Am J Pathol 163: 1261-1273, 2003. 
86. Ashcroft GS, Yang X, Glick AB, Weinstein M, Letterio JL, Mizel DE, Anzano M, Greenwell-Wild T, Wahl SM, Deng C and Roberts AB: Mice lacking Smad3 show accelerated wound healing and an impaired local inflammatory response. Nat Cell Biol 1: 260-266, 1999.

87. Chin YT, Liao YW, Fu MM, Tu HP, Shen EC, Nieh S, Shih KC and Fu E: Nrf-2 regulates cyclosporine-stimulated HO-1 expression in gingiva. J Dent Res 90: 995-1000, 2011.

88. Schröder NW, Pfeil D, Opitz B, Michelsen KS, Amberger J, Zähringer U, Göbel UB and Schumann RR: Activation of mitogen-activated protein kinases p42/44, p38, and stress-activated protein kinases in myelo-monocytic cells by Treponema lipoteichoic acid. J Biol Chem 276: 9713-9719, 2001.

89. Kaisho T and Akira S: Toll-like receptor function and signaling. J Allergy Clin Immunol 117: 979-987, 2006.

90. Subramani T, Rao S, Senthilkumar K, Periasamy S and Alitheen NB: Angiotensin II stimulates expression of transcription factors c-Jun and c-Fos in cyclosporine induced human gingival fibroblasts. Biocell 37: 71-76, 2013.

91. O'Reilly SM and Moynagh PN: Regulation of Toll-like receptor 4 signalling by A20 zinc finger protein. Biochem Biophysic Res Commun 303: 586-593, 2003.

92. Boone DL, Turer EE, Lee EG, Ahmad RC, Wheeler MT, Tsui C, Hurley P, Chien M, Chai S, Hitotsumatsu O, McNally E, Pickart C and Ma A: The ubiquitin-modifying enzyme A20 is required for termination of Toll-like receptor responses. Nat Immunol 5: 1052-1060, 2004.

93. Yokota S, Okabayashi T, Yokosawa N and Fujii N: Measles virus $\mathrm{P}$ protein suppresses Toll-like receptor signal through up-regulation of ubiquitin-modifying enzyme A20. FASEB J 22 $74-83,2008$.
94. Arslan F, Houtgraaf JH, Keogh B, Kazemi K, de Jong R, McCormack WJ, O'Neill LA, McGuirkP, Timmers L, Smeets MB, Akeroyd L, Reilly M, Pasterkamp G and de Kleijn DP: Treatment with OPN-305, a humanized anti-Toll-Like receptor-2 antibody, reduces myocardial ischemia/reperfusion injury in pigs. Circ Cardiovasc Interv 5: 279-287, 2012

95. Mizuno T, Kurotani T, Komatsu Y, Kawanokuchi J, Kato H, Mitsuma N and Suzumura A: Neuroprotective role of phosphodiesterase inhibitor ibudilast on neuronal cell death induced by activated microglia. Neuropharmacology 46: 404-411, 2004.

96. Rolan P, Gibbons JA, He L, Chang E, Jones D, Gross MI, Davidson JB, Sanftner LM and Johnson KW: Ibudilast in healthy volunteers: safety, tolerability and pharmacokinetics with single and multiple doses. Br J Clin Pharmacol 66: 792-801, 2008.

97.Zeisberg EM1, Tarnavski O, Zeisberg M, Dorfman AL, McMullen JR, Gustafsson E, Chandraker A, Yuan X, Pu WT, Roberts AB, Neilson EG, Sayegh MH, Izumo S and Kalluri R: Endothelial-to-mesenchymal transition contributes to cardiac fibrosis. Nat Med 13: 952-961, 2007

98. Czeslick E, Struppert A, Simm A and Sablotzki A: E5564 (Eritoran) inhibits lipopolysaccharide-induced cytokine production in human blood monocytes. Inflamm Res 55: 511-515, 2006

99. Hennessy EJ, Parker AE and O'Neill LA: Targeting Toll-like receptors: emerging therapeutics. Nat Rev Drug Discov 9: 293-307, 2010.

100. Connolly DJ and O'Neill LA: New developments in Toll-like receptor targeted therapeutics. Curr Opin Pharmacol 12: $510-518,2012$. 